\title{
PENGARUH MODEL PEMBELAJARAN GROUP INVESTIGATION (GI) TERHADAP BERPIKIR KRITIS DAN KETERAMPILAN SOSIAL SISWA DALAM PEMBELAJARAN IPA BIOLOGI KELAS X SMAN 2 ARGAMAKMUR
}

\author{
Meti Herlina $^{1^{*}}$, Isti Yesti Rahayu ${ }^{1}$, Diningsih Wiksya ${ }^{1}$ \\ ${ }^{1}$ Program Studi Pendidikan Biologi, Fakultas Keguruan dan Ilmu Pendidikan, Universitas Muhamadiyah \\ Bengkulu \\ email: metyalina@umb.ac.id
}

\begin{abstract}
Abstrak
Penelitian ini bertujuan untuk membangun kemampuan berpikir tingkat tinggi siswa dan keterampilan sosial siswa. Jenis penelitian ini adalah penelitian kuasi eksperimen. Menggunakan rancangan penelitian Randomized control-group Pretest-Posttest Design. Sampel penelitian ini siswa dibagi menjadi 2 kelompok yaitu kelompok eskperimen dan kelompok kontrol. Adapun teknik pengumpulan data kemampuan berpikir kritis menggunkan lembar analisis kemampuan berpikir kritis dan untuk keterampilan sosial menggunakan angket keterampilan sosial. Teknik analisis data yang digunakan untuk menguji hipotesis dalam penelitian ini adalah menggunakan uji-t tidak berpasangan. Hasil dari uji-t bahwa sig. (2-tailed) sebesar 0,000 lebih kecil dari 0,05. Hasil analisis menunjukkan bahwa terdapat pengaruh model pembelajaran Group Investigation (GI) tehadap hasil berpikir kritis dan keterampilan sosial siswa.
\end{abstract}

Kata kunci :Group Investigation, Berpikir Kritis, Keterampilan Sosial

\begin{abstract}
This study aimed at finding out the effect of applying Group Investigation (GI) learning model on students' critical thinking and social skills in Biological Science Learning Class $X$ at Senior High School Number 2 Argamakmur. This type of studywas experimental research. This study employed a randomized controlgroup pretest-posttest design as its study design. The sample of this study was divided into 2 groups namely experimental and control group.The data analysis technique was used to test the hypothesis in this study is namely by applying the t-test. The results of this study indicate that there are effects of the results of critical thinking and students' social skills on plant material between the Group Investigation (GI) learning and conventional learning. The results of students' critical thinking in the experimental class were higher than the control class, the average value of students' critical thinking in the experimental class was 76.82 while in the control class was 48.94 . Whereas the average social skills of the experimental class students was 120.83 and in the control class was 101.84 . Based on the hypothesis, it can be concluded that the use of the Group Investigation (GI) model in the experimental class significantly gave effect on the students 'critical thinking and students' social skills.
\end{abstract}

Keywords: GI, Critical Thinking, Social Skills 


\section{PENDAHULUAN}

Salah satu masalah yang dihadapi dunia pendidikan kita adalah masalah lemahnya proses pembelajaran baik di sekolah maupun perguruan tinggi. Mata pelajaran sains tidak dapat mengembangkan kemampuan anak untuk berpikir kritis dan sistematis karena dalam proses pembelajaran, anak kurang didorong untuk mengembangkan kemampuan berpikir dan keterampilan proses Sains. Proses pembelajaran di dalam kelas diarahkan kepada kemampuan anak untuk menghafal informasi, otak anak dipaksa untuk mengingat dan menimbun berbagai informasi tanpa dituntut untuk memahami dan menguasai informasi yang diingat untuk menghubungkan mereka dengan kehidupan sehari-hari. Dampak dari pola pembelajaran seperti itu anak tidak memahami dan menguasai konsep yang diajarkan. Rendahnya penguasaan konsep sains disebabakan oleh pola pikir yang rendah pada pembentukan sistem konseptual yang tidak mengembangkan kemampuan berpikir tingkat tinggi (Jalaludin, 2009).

Sedangkan menurut Trianto (2011) proses pembelajaran terutama di sekolah masih memberikan dominasi guru dan tidak memberikan akses bagi siswa untuk berkembang secara mandiri melalui penemuan dalam proses berpikirnya tingkat tinggi. Hal ini membuat kualitas pendidikan yang masih rendah.

Tujuan pokok dari penyelenggaraan kegiatan pembelajaran disekolah adalah membelajarkan siswa agar mampu memproses dan mampu memperoleh pengetahuan keterampilan dan sikap bagi dirinya sendiri. Dimana kemampuan belajar yang baik dapat membangun pikiran anak yang kritis dan aktif (Dimyati dan Mujiono, 2009).
Berdasarkan observasi awal di SMAN 2 Argamakmur pada bulan Oktober 2018 diperoleh informasi dari salah satu guru Biologi kelas $X$ SMAN 2 Argamakmur menggunakan kurikulum 2013 (K13), dengan Kriteria Ketuntasan Minimal (KKM) sekolah untuk mata pelajaran Biologi yaitu 75. Dimana model yang digunakan dalam pembelajaran Biologi dikelas $\mathrm{X}$ adalah model pembelajaran konvensional melalui metode ceramah dan diskusi biasa yang belum membantu mendidik siswa untuk aktif dan membangun keterampilan berpikir kritis. Penggunaan model Group Investigation dalam Pembelajaran ini guru memegang peranan yang sangat penting (Teacher Centered) dimana guru lebih aktif menjelaskan dibandingkan siswa yang diberikan kesempatan untuk menemukan dan memecahkan masalah yang dapat membangun kemamapuan berpikir kritis. Selain itu dalam menyampaikan materi guru terkadang menggunakan slide power point. Dalam proses pembelajaran guru juga memberikan tugas kepada siswa untuk merangkum materi pembelajaran, mengerjakan soal-soal yang ada pada buku paket dan sesekali memberikan selembaran bahan diskusi sehingga siswa tidak terbiasa belajar bekerjasama dalam kelompok, yang mampu mengasa keterampilan sosial siswa. Selain juga dikatakan bahwa pada saat proses pembelajaran Biologi berlangsung ada beberapa siswa yang masih pasif. Hal ini ditunjukan dari sedikit siswa yang aktif mengajukan pertanyaan dan proses pembelajaran seperti kurangan mengembangkan kemampuan berpikir tingkat tinggi dan keterampilan sosial siswa.

Salah satu faktor yang mempengaruhi keberhasilan dari proses belajar mengajar adalah model pembelajaran. Penggunaan model 
pembelajaran yang tepat dapat mempermudah peserta didik memahami konsep, mengembangkan kemampuan kerjasama, berfikir kritis dan sikap percaya diri. Sehingga dalam pembelajaran dapat tercipta interaksi yang lebih luas, yaitu interaksi dan komunikasi yang dilakukan antara guru dengan siswa, siswa dengan siswa, dan siswa dengan guru (multi way traffic communication) (Abdulhak; Rusman, 2010).

Model pembelajaraan Group Investigation (GI) merupakan model pembeajaran yang dapat meningkatkan kemampuan berfikir kritis siswa. Siswa dituntut dalam suatu kegiatan mental untuk mencermati suatu peryataan dan berfikir yang menekankan perbuatan keputusan tentang jawaban alternatif yang benar (Wijayanti dkk, 2013).

Sejalan dengan pendapat (Dewi, 2015) bahwaModel pembelajaran Group Investigation mempunyai tujuan yaitu mengembangkan kemampuan siswa dalam rangka partisipasi sosial. Pengembangan kemampuan tadi akan melatih kecakapan berfikir tingkat tinggi dan menunjang keterampilan sosial siswa. Dimana keadaan tersebut akan menimbulkan sikap lebih peduli, aktif dalam mengajukan pertanyaan dan menjadi pendengar yang baik dari setiap informasi yang diterima. Berdasarkan hasil penelitian yang dilakukan sebelumnya oleh Sahfriana, dkk (2015) Menyimpulkan bahwa: 1) Hasil data diperoleh menunjukan adanya peningkatan kemampuan berfikir kritis di siklus I dan II sebesar 8,8\% dari 76,9\% ke $85,7 \%$. 2). Berdasarkan hasil observasi yang telah dilakukan, terdapat peningkatan keterampilan sosial sebesar 2,53 dari siklus I sebesar 33,55 ke siklus II sebesar 36,08. Efendi, (2017) hasil penelitian menunjukkan pengunaan model group investigationterbukti dapat meningkatkan kemampuan keterampilan sosial siswa. Berdasarkan urain latar belakang di atas maka penelitian ini bertujuan untuk mengetahui "Pengaruh Model Pembelajaran Group Investigation (GI) Terhadap Berfikir Kritis Dan Keterampilan Sosial Siswa Dalam Pembelajaran IPA Biologi Kelas X SMAN 2 Argamakmur".

\section{METODE}

Rancangan penelitian ini adalah rancangan menggunakan Random ControlGroup Pretest dan Posttest Design, dimulai dengan memberikan pretest (T1) untuk mengetahui kemampuan awal siswa. Kedua kelas ini baik kelas eksperimen maupun kelas kontrol akan diberi test yang sama. Selanjutnya kelas eksperimen akan diberi pembelajaran dengan model Group Investigation (GI) dimana diawali siswa dibagi dalam kelompok, siswa mengidentifikasi topik atau permasalahan. Melakukan perencanakan, melakukan investigasi, pelaporan, persentasi dan evaluasi (Perlakuan X2). Kelas kontrol diberi pembelajaran dengan model konvensional dengan metode ceramah tanya jawab untuk (Perlakuan X2). Selanjutnya setiap siswa baik kelas eksperimen maupun kelas kontrol diberi posttest (T2) yang sama dan diberikan angket keterampilan sosial untuk mengetahui keterampilan sosial siswa. Kemampuan berpikir kritis siswa akan dihitung rata-rata dn diuji dengn menggunakan $u j i$ beda (uji-t) tidak berpasangan.

Penelitian dilaksanakan di SMA Negeri 2 Argamakmur. Waktu penelitian dilaksanakan pada bulan Januari - Februari 2019. populasi penelitian ini yaitu seluruh siswa /siswi kelas X IPA di SMA Negeri 2 
Argamakmur yang berjumlah 66 orang 47 orang laki-laki dan 19 orang perempuan. Sampel yang digunakan dua kelompok sampel penelitian yaitu kelompok eksperimen dan kelompok kontrol. Kelompok eksperimen kelas $X$ IPA 1 sedangkan kelompok kontrol kelas X IPA 2. Jenis Penelitian kuasi eksprimen.

Teknik pengumpulan data yang digunakan dalam penelitian ini adalah tes dan angket. Untuk berpikir kritis menggunakan instrumen soal essai dan keterampilan sosial menggunakan angket keterampilan sosial. Angket yang digunakan yaitu angket yang diadopsi dan diadaptasi dari Theresia (2017). Angket disajikan dalam bentuk yang disesuaikan untuk mengukur keterampilan sosial siswa.sehingga responden diminta untuk memilih satu jawaban yang sesuai dengan karakteristik dirinya dengan cara memberikan tanda checklist ( $\mathrm{V}$ ). Analisis data pada penelitian ini berguna untuk menguji hipotesis dalam penelitian ini. Analisis yang digunakan dalam penelitian ini yaitu menggunkan uji-t, proses pengolahan data dengan menggunakan program Statistic Package For Social Science (SPSS) For Versi 21.0. Sebelum melkukn uji terlebih dahulu dilakakukan uji normalitas dan homogenitas.

\section{HASIL DAN PEMBAHASAN}

\section{Deskripsi Data Hasil Belajar Siswa \\ a. Test awal (Pretest)}

Data hasil pretest dapat dilihat pada Tabel 1. Berdasarkan Tabel 1. diatas, dapat diketahui bahwa hasil pretest kelas eksperimen mempunyai nilai rata-rata sebesar 42,57 skor tertinggi 80 dan skor terendahnya 15 . Sedangkan hasil pretest kelas kontrol mempunyai nilai rata-rata sebesar 36,06 dengan skor tertinggi 70 dan skor terendah 15. Disimpulkan bahwa ratarata pretest siswa kelas ekperimen dan kelas kontor sama.

Tabel 1. Perhitungan Skor Hasil Belajar Siswa Berdasarkan Tes Awal (pretest)

\begin{tabular}{|c|c|c|}
\hline \multirow[t]{2}{*}{ Perhitungan } & \multicolumn{2}{|c|}{ Kelas } \\
\hline & Eksperimen & Kontrol \\
\hline Jumlah Skor & 1405 & 1190 \\
\hline Rata-rata & 42.57 & 36.06 \\
\hline Skor Tertinggi & 80 & 70 \\
\hline Skor Terendah & 15 & 15 \\
\hline Jumlah Siswa & 33 & 33 \\
\hline
\end{tabular}

akan dilakukan uji prasyarat yaitu uji normalits dan homogenitas terlebih dahulu. Uji normlitas dilakukan untuk mengetahui apakah hasil pretest siswa tersebut berdistribusi normal atau tidak dan uji homogenits dilakukan untuk mengetahui apakah hasil pretest tersebut homogen atau tidak. Uji normalitas untuk kelas eksperimen dan kelas kontrol dapat dilihat pada Tabel 2.

Tabel 2. Hasil Uji Normalitas Nilai Pretest

\begin{tabular}{llr}
\multicolumn{3}{c}{ One-Sample Kolmogorov-Smirnov Test } \\
\hline $\mathrm{N}$ & \multicolumn{1}{c}{ Pretest } \\
\hline \multirow{3}{*}{ Normal Parameters $^{\mathrm{a}, \mathrm{b}}$} & \multicolumn{1}{c}{ Mean } \\
\cline { 2 - 3 } & Std. & 39.32 \\
\hline \multirow{2}{*}{$\begin{array}{l}\text { Most Extreme } \\
\text { Differences }\end{array}$} & Deviation & 16.217 \\
\cline { 2 - 3 } & Absolute & .135 \\
\cline { 2 - 3 } & Positive & .135 \\
\hline Kolmogoroverive & -.109 \\
\hline Asymp. Sig. (2-tailed) & & 1.099 \\
\hline
\end{tabular}

Berdasarkan Tabel 2. uji normlitas menggunakan uji one-sample Kolmogorovsmirnov test diatas didapatkan bahwa kelas eksperimen dan kelas kontrol memiliki nilai sig 0,178 lebih besar dari 0,05 $(0,178>0,05)$ 
Hal menunjukan bahwa kedua data tersebut berdistribusi normal.

Tabel 3. Hasil Uji Homogenitas Nilai Pretest Test of Homogeneity of Variances

\begin{tabular}{cccc}
\hline Pretest & & & \\
\hline Levene Statistic & df1 & df2 & Sig. \\
\hline .048 & 1 & 64 & .828
\end{tabular}

Berdasarkan Tabel 3. hasil uji homogenitas dengan menggunakan uji levene statistic pada spss 21.0 dihasilkan nilai signifikan sebesar 0,828 yang artinya lebih besar dari $0,05(0,828>0,05)$ sehingga dapat disimpulkan bahwa hasil pretest siswa mempunyai varian yang homogeny.

\section{b. Tes Akhir (Posttest)}

Data hasil posttest dapat dilihat pada Tabel 4.

Tabel 4. Perhitungan Skor Berpikir Kritis Siswa Berdasarkan Tes Akhir (posttest)

\begin{tabular}{lcc}
\hline \multicolumn{1}{c}{ Perhitungan } & \multicolumn{2}{c}{ Kelas } \\
\cline { 2 - 3 } & Eksperimen & Kontrol \\
\hline Jumlah Skor & 2535 & 1615 \\
\hline Rata-rata & 76.82 & 48.94 \\
\hline Skor Tertinggi & 95 & 80 \\
\hline Skor Terendah & 60 & 15 \\
\hline Jumlah Siswa & 33 & 33 \\
\hline
\end{tabular}

Berdasarkan Tabel 4. diatas, dapat diketahui bahwa hasil posttest kelas eksperimen mempunyai nilai rata-rata sebesar 76,82. Sedangkan hasil posttest kelas kontrol mempunyai nilai rata-rata sebesar 48,94. Sebelum melakukan uji hipotesis akan dilakukan uji parsyarat yaitu uji normalitas dan homogenitas terlebih dahulu. Uji normlitas dilakukan untuk mengetahui apakah hasil posttest siswa tersebut berdistribusi normal atau tidak dan uji homogenits dilakukan untuk mengetahui apakah hasil postest tersebut homogen atau tidak.

Berikut ini merupakan uji normlitas data nilai postest pada kelas eksperimen dengan menggunakan model pembelajaran Group Investigation (GI) dan kelas kontrol menggunakan model konvensional.

Tabel 5. Hasil Uji Normalitas Nilai Postes One-Sample Kolmogorov-Smirnov Test

\begin{tabular}{llr}
\hline & & Posttest \\
\hline $\mathrm{N}$ & Mean & 66 \\
\cline { 2 - 3 } Normal & Std. Deviation & 64.32 \\
\hline \multirow{2}{*}{$\begin{array}{l}\text { Most Extreme } \\
\text { Differences }\end{array}$} & Absolute & 17.539 \\
\cline { 2 - 3 } & Positive & .100 \\
\cline { 2 - 3 } & Negative & .062 \\
\hline Kolmogorov-Smirnov Z & .100 \\
\hline \multicolumn{2}{l}{ Asymp. Sig. (2-tailed) } & .510 \\
\hline
\end{tabular}

Berdasarkan Tabel 5. uji normlitas menggunakan uji one-sample Kolmogorovsmirnov test diatas didapatkan bahwa kelas eksperimen dan kelas kontrol memiliki nilai sig 0,528 lebih besar dari 0,05 (0,528>0,05) Hal menunjukan bahwa kedua data tersebut berdistribusi normal. Data hasil uji homogenitas dengan menggunakan IBM SPSS Statistics 21 dapat dilihat pada Tabel 6.

Tabel 6. Hasil Uji Homogenitas Nilai Postest Test of Homogeneity of Variances

\begin{tabular}{cccc}
\hline Posttest & & & \\
\hline Levene Statistic & df1 & df2 & Sig. \\
\hline 1.986 & 1 & 64 & .164
\end{tabular}

Berdasarkan Tabel 6. hasil uji homogenitas dengan menggunakan uji levene statistic pada spss 21.0 dihasilkan nilai signifikan sebesar 0,164 yang artinya lebih besar dari $0,05(0,164>0,05)$ sehingga 
dapat disimpulkan bahwa hasil posttest siswa mempunyai varian yang homogen. Setelah diketahui bahwa data posttest hasil belajar siswa berdistribusi normal dan mempunyai varians yang homogeny maka untuk melihat pengaruh posttest antara kelas eksperimen yang menggunakan model pembelajaran Group Investigation (GI) dan kelas kontrol menggunakan model konvensional dilanjutkan dengan uji-t hasilnya.

Dari Tabel 7. dapat dilihat hasil uji $\mathrm{t}$ diperoleh nilai signifikan sebesar 0,000 lebih kecil dari $0,05(0,000>0,05)$ serta $T_{\text {hitung }}$ 8.256dan $T_{\text {tabel }} 1.998$ artinya $T_{\text {hitung }} 8.256$ lebih besar dari $T_{\text {tabel }} 1.998$ sehingga dari tabel postest hasil kemampuan berpikir kritis diatas dapat disimpulkan model pembelajaran Group Investigation (GI) berpengaruh terhadap hasil belajar siswa kelas eksperimen. Jadi $\mathrm{H}_{0}$ ditolak dan $\mathrm{H}_{1}$ diterima.

Tabel 7. Hasil Uji Hipotesis

\begin{tabular}{ccc}
\hline $\begin{array}{c}\text { t-test for } \\
\text { Equality of } \\
\text { Means }\end{array}$ & \multicolumn{2}{c}{$\begin{array}{c}\text { Posttest hasil kemampuan } \\
\text { berpikir kritis siswa }\end{array}$} \\
\cline { 2 - 3 } & $\begin{array}{c}\text { Equal } \\
\text { variances } \\
\text { assumed }\end{array}$ & $\begin{array}{c}\text { Equal } \\
\text { variances not } \\
\text { assumed }\end{array}$ \\
\hline $\mathrm{T}$ & 8.256 & 8.256 \\
\hline Df & 64 & 60.858 \\
\hline Sig (2- tailed) & .000 & .000 \\
\hline
\end{tabular}

\section{a. Analisis Data Angket Keterampilan Sosial}

Berdasarkan Tabel 8. diperoleh nilai rata - rata keterampilan sosial belajar siswa kelas eksperimen 120,83. Kelas kontrol mendapatkan rata - rata 101,84. Untuk mengetahui pengaruh model Pembelajaran kooperatif tipe Grup Investigation (GI) terhadap keterampilan social belajar siswa menggunakan uji t. Sebelum melakukan uji t dilakukan terlebih dahulu uji prasyarat yaitu uji normalitas dan uji homogenitas. Hasil uji normalitas keterampilan sosial siswa menggunakan uji Kol mogorov - Smirnov pada IBM SPSS Statistics 21.

Tabel 8. Hasil Skor Angket Keterampilan Sosial Siswa

\begin{tabular}{lcc}
\hline \multirow{2}{*}{ Perhitungan } & \multicolumn{2}{c}{ Kelas } \\
\cline { 2 - 3 } & Eksperimen & Kontrol \\
\hline Jumlah Skor & 3981 & 3366 \\
\hline Rata-rata & 120,83 & 101,84 \\
\hline Jumlah Siswa & 33 & 33
\end{tabular}

Berikut ini merupakan uji normalitas data angket keterampilan sosial siswa pada kelas eksperimen dengan menggunkan model pembelajaran tipe Grup Investigation (GI) dan kelas kontrol dengan menggunakan model konvensional.

Tabel 9. Hasil Uji Normalitas Nilai Angket Keterampilan Sosial

One-Sample Kolmogorov-Smirnov Test

\begin{tabular}{llr} 
& & angket KS \\
\hline $\mathrm{N}$ & & 66 \\
\hline \multirow{2}{*}{$\begin{array}{l}\text { Normal } \\
\text { Parameters }\end{array}$} & Mean & 111.32 \\
\cline { 2 - 3 } & $\begin{array}{l}\text { Std. } \\
\text { Meviation }\end{array}$ & 16.087 \\
\hline \multirow{2}{*}{\begin{tabular}{l} 
Differences \\
\cline { 2 - 3 }
\end{tabular}} & Absolute & .160 \\
\cline { 2 - 3 } & Positive & .076 \\
\cline { 2 - 3 } Kolmogorov-Smirnov Z & -.160 \\
\hline Asymp. Sig. (2-tailed) & 1.300 \\
\hline
\end{tabular}

Berdasarkan Tabel 9. diatas dapat dilihat bahwa tingkat signifikansi baik kelas eksperimen maupun kelas kontrol memiliki tingkat signifikansi yang lebih besar dari 0,05 $(0,68>0,05)$. Hal tersebut menunjukkan bahwa kedua data tersebut berdistribusi normal. Setelah diketahui angket berdistribusi normal selanjutkan akan 
menggunakan uji homogenitas. Hasil homogenitas siswa dapat dilihat pada tabel berikut:

Tabel 10. Hasil Uji homogenitas Angket keterampilan social

\begin{tabular}{lccc}
\hline \multicolumn{4}{c}{ Test of Homogeneity of Variances } \\
\begin{tabular}{cccc}
\hline angket minat \\
\hline Levene Statistic & df1 & df2 & Sig. \\
\hline 3.391 & 1 & 64 & .070 \\
\hline
\end{tabular}
\end{tabular}

Dari data tabel diatas dapat diketahui nilai Signifikan $(0,070)>0,05$. Jadi data tersebut merupakan data yang homogeny, maka data mempunyai nilai varian yang sama/tidak berbeda (homogen). Setelah uji prasyarat terpenuhi, dilakukan uji hipotesis. Berdasarkan Tabel 11. dapat kita lihat hasil perhitungan SPSS Statistic 21 diperoleh nilai sig lebih kecil dari $0,05(0,02<0,05)$ ini berarti $\mathrm{H} 0$ ditolak dan $\mathrm{H} 1$ diterima, dengan demikian terdapat pengaruh model Group Investigation terhadap Keterampilan Sosial Siswa di SMAN 2 Argamakmur.

Tabel 11. Hasil Uji Hipotesis

\begin{tabular}{|c|c|c|}
\hline \multirow{2}{*}{$\begin{array}{l}\text { t-test for } \\
\text { Equality of } \\
\text { Means }\end{array}$} & \multicolumn{2}{|c|}{ Minat siswa } \\
\hline & $\begin{array}{c}\text { Equal } \\
\text { variances } \\
\text { assumed }\end{array}$ & $\begin{array}{c}\text { Equal variances not } \\
\text { assumed }\end{array}$ \\
\hline $\mathrm{T}$ & 5.750 & 5.750 \\
\hline Df & 64 & 50.776 \\
\hline $\begin{array}{l}\text { Sig } \\
\text { tailed })\end{array}$ & .000 & .000 \\
\hline
\end{tabular}

Berdasarkan hasil frekuensi keterampilan sosial siswa pada Tabel 12 . keterampilan sosial siswa kelas eksperimen diperoleh 24 orang siswa $(72,7 \%)$ dengan keterampilan sosial tinggi, 9 orang siswa $(38,1 \%)$ dengan kategori sedang, sedangkan untuk kategori rendah 0 siswa. Keterampilan sosial siswa kelas kontrol yaitu 3 orang siswa $(9,09 \%)$ dengan kategori keterampilan sosial tinggi, 25 orang siswa $(75,7 \%)$ dengan kategori sedang dan untuk kategori rendah $15(15,1 \%)$ siswa.

Tabel 12. Keterampilan Sosial Siswa

\begin{tabular}{llllll}
\hline No & Kriteria & \multicolumn{2}{c}{ Eksperimen } & \multicolumn{2}{c}{ Control } \\
\cline { 3 - 6 } & & $\begin{array}{c}\text { Freku } \\
\text { ensi }\end{array}$ & $\begin{array}{c}\text { Present } \\
\text { ase }\end{array}$ & $\begin{array}{c}\text { Fre } \\
\text { kue } \\
\text { nsi }\end{array}$ & $\begin{array}{c}\text { Presen } \\
\text { tase }\end{array}$ \\
\hline 1. & $\begin{array}{l}115-140 \\
\text { (Tinggi) }\end{array}$ & 24 & $72,7 \%$ & 3 & $9,09 \%$ \\
\hline 2. & $\begin{array}{l}70-114 \\
\text { (Sedang) }\end{array}$ & 9 & $27,2 \%$ & 25 & $75,7 \%$ \\
\hline 3. & $\begin{array}{l}63-70 \\
\text { (Rendah) }\end{array}$ & 0 & $0 \%$ & 5 & $15,1 \%$ \\
\hline
\end{tabular}

Dari hasil analisis pengaruh model pembelajaran Group Investigation terhadap kemampuan berpikir kritis siswa, berdasarkan uji-t posttetst (test akhir) bahwa terdapat pengaruh yang signifikan antara model pembelajaran Group Investigation terhadap kemampuan berpikir kritis siswa di kelas eksperimen dan kelas kontrol.

Hal ini karena dalam proses pembelajaran Group Investigation pelaksanaannya siswa lebih banyak diberikan kebebasan untuk terlibat langsung dalam proses pembelajaran seperti penetuan topik, menginvestigasi dan memperoleh informasi serta mendiskusikan jawaban dari permasalah yang diterima. Karena adanya keterlibatan seluruh siswa di dalam diskusi kelompok sehingga dapat membuat siswa menjadi lebih aktif. Dengan demikian dapat memberi pengaruh pada kemampuan berpikir kritis siswa. Selain itu, model pembelajaran Group Investigtaion merupakan model pembelajaran yang dapat melibatkan pengalaman kehidupan seharihari siswa dalam proses pembelajaran. 
Siswa dalam kelompok diberikan kebebasan untuk menentukan topik permasalah, merencanakn penyelesain dengan metode ilmiah, dengan melakukan pengumpulan data dengan melakuakan inverstigasi, menganilisis, mensitesis, dan mengambil keputusan/kesimpulan dari dari data yang telah didapat untuk permaslah yang telah ditentukan, melakukan pelaporan dan evaluasi dalam kelompok. Dari proses pembelajaran seperti itu akan menumbuhkan cara berpikir kritis siswa dan kerjasama kelompok yang tercipta dalam proses pembelajaran sangat membantu membangun keterampilan sosial. Hal ini sesuai dengan penelitian Yuli (2013) yang menyatakan model pembelajaran Group Investigation dapat membantu guru memberikan gambaran orientasi topik kepada siswa yang terkait dengan permasalahan disekitar mereka dan melibatkan meraka secara aktif serta belajar berkerjasama dengan kelompok, membuat referensi dan hasil permasalahan terkait topik permasalahan mereka, sehingga dapat meningkatkan kemampuan berpikir tingkat tinggi.

Model pembelajaran Group Investigation yang kembangkan oleh Sharan dan Sharen pada tahun 1970 juga dapat menciptakan situasi belajar mengjar yang banyak memberikan kesempatan kepada siswa untuk memecahkan masalah dan mengembangkan konsep atau gagasan siswa sendiri, yang akan memicu rasa keingintahuan siswa dan mendukung pengebangan kerjasama kelompok yang akan berpengaruh terhadap kemampuan berpikir kritis siswa. Senada dengan pernyataan Manik (2015) yang menyatakan bahwa Group Investigation pada dasarnya memungkinkan siswa melakukan kegiatan untuk mengembangkan keterampilan sikap dan pemahaman serta membantu siswa untuk memacu rasa keingintahuannya tentang materi yang diajarkan, sehingga suasana belajar dapat kondusif dan menjadikan pembelajaran aktif yang memungkinkan siswa mengembangkan kemampuan berpikir tingkat tingginya. Sejalan juga dengan pendapat Sahfriana, dkk ( 2015) yang menyatakan bahwa dengan menggunakan model pembelajaran Group Investigation dapat mengembangkan kemampuan siswa dalam rangka partisipasi proses sosial dimana pengembangan kemampuan tadi akan melatih kecakapan tingkat tinggi siswa.

Berbeda halnya dengan kelas kontrol yang hanya memperoleh skor rata-rata tes akhir (posttest) 48,94. Hal ini dikarenakan model yang digunakan adalah model pembelajaran konvensional yang terpusat pada guru (teacher centered). Dimana dalam proses pembelajarannya, siswa hanya mengandalkan penjelasan dari guru dan hanya dituntut pada daya ingat atau hapalan. Sehingga hal tersebut membuat siswa menjadi kurang aktif dalam menguasi materi yang diajarkan. Proses pembelajaran seperti ini akan menghambat pencapaian pemahaman konsep dan keterampilan berpikir kritis siswa. Hal ini sesuai dengan pendapat Aslahah, dkk (2014) yang menyatakan bahwa dengan model pembelajaran konvensional menggunakan metode ceramah dan tanya jawab yang berpusat pada guru cenderung tidak mampu membuat siswa aktif dalam menyampaikan pendapatnya ketika mendapat permasalahan dari guru, dengan demikian kemampuan berfikir siswa, termasuk kemampuan berpikir kritis akan sulit untuk berkembang. 


\section{Pengaruh Model Pembelajaran Group Investigation (GI) Terhadap Keterampilan Sosial Siswa.}

Berdasarkan hasil penelitian yang telah dilakukan bahwa terdapat pengaruh model pembeelajaran Group Investigation terhadap keterampilan sosial siswa di SMAN 2 dilihat dari nilai sig. (2-tailed sebesar 0,000 lebih kecil dari 0,05.

Hal tersebut karena dalam pembelajaran Group Investigation dapat menciptakan suasana pembelajaran yang menarik dan menyenangkan. Hal ini dikarenakan pada saat proses pembelajaran guru memberikan topik dan masalah untuk dikerjakan secara mandiri bersama kelompok. Guru hanya sebagai fasilitator sehingga siswa disni dibimbing untuk lebih aktif berkejasama dengan kelompok sehingga dengan adanya kerja kelompok tersebut akan membangaun keteramilan sosial masing-masing individu. Hal ini sejalan dengan pendapat Pramudyanti (2012) yang menyatakan jika pembelajaran yang memberikan kesan menyenangkan akan meningkatkan keterampilan sosial melalui pembelajaran siswa secara langsung pada objek yang dipelajari. Sama halnya dengan pendapat Wahyudi (2011) yang menyatakan bahwa banyak alasan siswa mengatakan pembelajaran model Group Investigation menyenangkan, diantaranya kelas lebih terasa seru dengan mampu berdiskusi dalam kelompok kecil, berani berargumen didepan kelas serta berani bertanya dan membuat model persentasi yang unik dan menarik.

Model pembelajaran Group Investigation dapat membuat siswa saling berkerja sama dalam kelompok untuk menetukan suatu informasi (gagasan, opini, data, solusi ). Dalam proses pembelajarn guru membagi siswa dalam beberapa kelompok dan membagikan topik permasalahn untuk dikerjakan mandiri bersama kelompok, dalam kelompok siswa saling berdiskusi dan melakuakn investigasi sesuai dengan topik yang diberikan untuk menghasilkan pemecahan masalah. Sehingga dengan hal tersebut dapat membuat siswa akan saling berkomunikasi, saling mendengarkan, saling berbagi, saling memberi dan menerima yang nantinya akan melatih kecapan keterampilan sosial siswa. Hal ini sesuai dengan pendapat Retno (2014) yang menyatakan bahwa model pembelajaran Group Investigation (GI) dapat mengebangkan ketrampilan sosial pada siswa diantaranya: 1) meningkatkan belajar berkerjasama, 2) meningkatkan komunikasi baik dengan teman sendiri maupun guru, 3) melatih siswa menghargai pendapat orang lain, 4) menjadikan siswa lebih kreatif dan berpartisipasi dalam membuat keputusan. Sehingga dengan cara ini dapat menjamin keterlibatan seluruh siswa di dalam diskusi kelompok. Hal ini juga didukung dengan pendapat Sarimaya (2009) yang menyatakan bahwa dengan adanya partisipasi siswa dalam proses belajar mengajar akan berdampak pada meningkatnya keterampilan sosial siswa.

Selain itu, model pembelajaran Group Investigation ini dapat membuat siswa lebih tertarik dalam mengikuti pelajaran dan percaya diri dalam mengutarakan gagasan, memecahkan masalah secara bersama-sama dan mengkomunikasikan hasil diskusi kelompoknya di depan kelas. Dengan demikian akan terjalin suatu interaksi yang memicu meningkatnya keterampilan sosial siswa. Sesuai dengan pendapat Nur, dkk (2015) dalam penelitiannya yang menyatakan bahwa model pembelajaran Group Investigation (GI) efektif diterapkan 
dalam proses pembelajaran. Hal ini dikarenakan suasana pembelajaran yang demokratis dimana siswa dibebaskan untuk berpendapat dan memberikan opini sehingga memberi kesempatan bagi siswa untuk memperoleh informasi melalui proses investigasi, yang mampu membangun keterampilan sosial yang bermanfaat dalam kehidupan bermasyarakat.

Berbeda halnya dengan kelas kontrol, dimana pada kelas kontrol masih ada siswa yang mendapatkan kategori rendah $(15,1 \%)$ sebanyak 15 siswa. Hal ini dikarenakan pada saat proses pembelajaran siswa hanya mengandalkan penjelasan dari guru serta interaksi antar siswa dalam bertukar pendapat atau informasi masih kurang dan juga dalam proses tanya jawab siswa yang terlibat masih sedikit. Dengan adanya hal tersebut, maka akan berdampak pada rendahnya keterampilan sosial siswa. Didukung dengan pendapat Sahfriana, dkk (2015) berdasarkan hasil obsevasi di dalam kelas eksperimen dengan menggunakan model GI terdapat peningkatan keterampilan sosial dikarenakan siswa telah mampu berkomunikasi dengan baik. Baik itu komunikasi antara teman satu dengan teman lainya maupun komunikasi siswa dengan lingkungan sekitarnya, yang juga dipengaruhi oleh luar diri siswa maupun guru sebagai fasilator yang memberi dorongan kepada siswa.. Sedangkan pada kelas kontrol dengan model konvensional, belum mampu berkomunikasi dengan baik,dimana interaksi siswa dengan guru lebih besar dibandingkan interaksi siswa dengan siswa.

\section{KESIMPULAN}

Berdasarkan hasil penelitian :Terdapat pengaruh model pembelajaran Group Investigation terhadap berpikir kritis dan keterampilan sosial siswa di SMAN 2 Argamakmur

\section{DAFTAR PUSTAKA}

Aslahah, H. Herawati, S. \& Prasetyo. (2014). Pengaruh Sterategi Pembelajaran Group Investigation (GI) Terhadap Kemampuan Berpikir Kritis Siswa SMA di Kota Malang. Artikel Universitas Negeri Malang.

Dimyati, Mudjiono. (2009). Belajar dan Pembelajaran. Jakarta: Rineka Cipta.

Efendi, L. M. (2017). Penerapan Model Pembelajaran Kooperatif Tipe Group Inverstigation untuk meningkatakan keterampilan sosial.Tesis. Universitas Lampung tidak diterbitkan.

Jalaludin. (2009). Penggunaan Model Pembelajaran Berbasis Masalah dengan Pendekatan Inkuiri $T$ erbimbing untuk Meningkatakan Penguasaan Konsep Listrik Dinamis dan Kecakapan ilamiah di SMA. Program Pasca Sarjana Pendidikan IPA Universitas Indonesia. Tesis. Bandung: Tidak diterbitkan.

Ninik, W. (2015). Penerapan Pembelajaran Kooperatuf Tipe Group Investigasi (GI) Untuk Meningkatkan Kemampuan Berfikir Kritis Siswa Di SMA Muhammadyah 4 Bengkulu. Skripsi Pendidikan Biologi Universitas muhammadyah Bengkulu.

Pramudyanti, C. (2012). Peningkatan Keterampilan Sosial Siswa Menggunkan Model Pembelajaran Tipe Team Games Tournament 
(TGT) Dalam Pembelajaran IPS Kecamatan Klaten, Kabupaten Bantul. Skripsi Pendidikan Universitas Negeri Yogyakarta.

Rusman. (2013). Model-Model Pembelajaran Mengembangkan Profesionalisme Guru. Jakarta: PT Raja Grafindo Persada.

Sahfrina. I., Wachyu, S. \& Suratno. (2015). Pengaruh Model Pembelajaran Group Investigation (GI) Dalam Meningkatkan Kemampuan Berfikir Kritis Dan Keterampilan Sosial Siswa Dalam Pembelajaran IPA Biologi Untuk Materi Ajar Pertumbuhan Dan Perkembangan Kelas 8-C Semester Gangsal Di SMP Negeri 1 Bangil Pasuruan. Jurnal Program Studi Pendidikan Biologi FKIP Unej, 4 (2), 213-222.

Sarimaya, F. (2009). Peningkatan Keterampilan Sosial Siswa SMP Dalam Pembelajaran IPS Melalui Pengembangan Model Pembelajaran Kooperatif. Jurnal Program Studi Pendidikan Sejarah Universitas Pendidikan Indonesia.

Trianto. (2011). Mendesain Model Pembelajaran Inovatif-Progresif (Konsep, Landasandan Implementasinya pada Kurikulum Tingkat Satuan Pendidikan (KTSP)). Prenada Media Group. Jakarta

Sumanik, M. (2015). Penggunaan Model Pembelajaran Group Investigation Untuk Mencapai Kopetensi Belajar Biologi Materi System Peredaran Darah Manusia Pada Siswa Kelas VII SMP St. Theresia Langgur-Maluku
Tenggara. Jurnal Pendidikan Biologi, 1 (2), 179-187.

Wijayanti. W., Herlambang. S., \& Slamet. Pengaruh Model Pembelajaran Group Investigation Terhadap Kemampuan Berfikir Kritis Siswa Kelas X SMA Negeri 1 Mejayan Kabupaten Mediun. Skripsi Jurusan Geografi Fakultas IImu Sosial Univesritas Negri Malang.

Yuli, N. Budi, H. Purwito. (2013). Model Pembelajaran Group Investigation (GI) Terhadap Kemampuan Berpikir Analis. Jurnal Program Studi Pendidikan Geografi Universitas Negeri Malang. 